\title{
A sustainable rice production technology: problems and prospects
}

\author{
A. K. Rohila*, B. S. Ghanghas, Pawan Kumar, P. S. Shehrawat and Rati Mukteshawar \\ Department of Extension Education, CCS Haryana Agricultural University, Hisar-125004 (Haryana), INDIA \\ *Corresponding author. E-mail : anil_bhana@yahoo.com
}

Received: February 14, 2015; Revised received: July 22, 2015; Accepted: August 28, 2015

\begin{abstract}
The study has focused on problems and prospects perceived by farmers' for growing rice in direct seeded cultivation mode i.e. Direct Seeded Rice (DSR) in Haryana (India). Overall adoption of DSR technology was low to moderate since 70 per cent respondents belonged to these categories. The method of sowing (weighted mean score 3.0), depth of sowing (2.93) and seed treatment (2.93) were highly adopted agronomic practices, whereas least adopted practices were like recommended seed rate (1.94), timely application of fertilizers (1.87) and their recommended doses (1.73), and ferrous sulphate use only at deficiency syndrome (1.19) not as per recommended schedule. Among constraints non-availability of quality seeds, fertilizers, weedicides and pesticides in required quantity and at proper time (1.64), high weed infestation in DSR in comparison to transplanting (2.88), wide fluctuation in prices (2.83) of basmati paddy due to lack of MSP, lack of storage facilities in villages (2.78), lack of proper knowledge of irrigation schedule (1.73), non-availability of extension personnel (1.64), lack of low credit facility (1.62), non-availability of agricultural magazines and literature in time in villages (2.78), lack of stable procurement policy for basmati rice (2.78) and lack of trained field staff to provide technical guidance during cultivation (2.02) process were serious constraints faced by farmers in adoption of DSR technology in Haryana. Since majority of respondent farmers agreed that DSR technology give better net returns in comparison to transplanting (2.95), less labour requirement (2.92) and best suited to climate change risks (2.66).
\end{abstract}

Keywords: Basmati Rice, Climate Change, Constraints, Direct Seeded Rice, Prospects

\section{INTRODUCTION}

Rice is the most prominent crop of India since it is the staple food of more than 70 per cent of population of the country. It also plays vital role in country's food security as well as providing livelihood to millions of rural households. India is the second largest producer of rice after China. Since independence its yield has increased four times due to increase in yield of improved varieties, area under rice approximately increased 40 per cent since 1950. In India demand for rice will increase because of population growth and change in dietary pattern. India is the leading exporter of the basmati market. India has exported 34,59,898 Million Tonnes of basmati rice to the world for the worth of Rs. 19,49.38 crores (Anonymous, 2013).

Therefore, the sustainability of rice-eco-system and ability to increase production in pace with population growth with reduced water and labor use and climate changes are major concerns in conventional method of cultivation of rice. Only direct-seeded rice (DSR) is feasible alternative with good potential to save water, reduce labour requirement, mitigation of green house gases (GHGs) emission and adaptability to climate risks. Mostly scientists now agree that rising atmospheric concentrations of GHG threaten to have severe impacts on food production, natural ecosystem and human health. (Mukteshawar et al., 2015).
Haryana is second largest state to contribute in central procurement pool of rice after Punjab. The yield is almost at par in case of basmati group if crop is properly managed for which CCS Haryana Agricultural University, Hisar have recommended package of practices of DSR cultivation in the year 2012. Presently, Haryana leads in production of aromatic basmati rice and more than 60 per cent export of basmati rice is undertaken from the state. Rice is grown on an area of 39.47 million hectare with total production of 87.10 million tonnes, with productivity of $2207 \mathrm{~kg} / \mathrm{ha}$ (Anonymous, 2012).

Keeping in view the above facts and importance of this technology towards sustainable production of rice for the country as a whole and Haryana (India) in particular, the study was conducted with the objectives to assess the farmers' adoption level, constraints perceived by them in adoption of technology, the prospects of this technology and a suitable extension strategy to promote the adoption of DSR technology.

\section{MATERIALS AND METHODS}

The study was conducted in Haryana state. Four districts Yamuna Nagar, Kurukshetra, Karnal and Kaithal were selected due to maximum cultivation of rice in these districts. From each district, one block with maximum area under DSR culture was selected viz. Sadhaura from Yamuna Nagar, Shahbad from 
Kurukshetra, Assand from Karnal and Pundri from Kaithal. Further two villages were selected from each block which have maximum DSR culture. From each village, 15 farmers were selected randomly, who were growing rice in DSR culture, making a total of 120 farmer respondents. The data were collected with the help of well-structured interview schedule developed by student under the supervision of advisory committee. The data were analyzed and tabulated after applying suitable statistical techniques like frequency, percentage, total weighted score, weighted mean score and rank orders. The responses were obtained on three-point continuum scale in case of adoption (fully adopted, partially adopted and not adopted), in case of constraints (very serious, serious and not so serious) and in prospects (agree, undecided and disagree) and scores were given as 3,2 and 1, respectively. After that frequency was multiplied with the score $(3,2$ or 1$)$ and total weighted score was obtained and total weighted score was divided by total respondents (120) for weighted mean score.

\section{RESULTS AND DISCUSSION}

Overall adoption level of DSR cultivation technology: Results pertaining to overall adoption of DSR cultivation technology presented in table 1 clearly show that majority of farmers (35.83 per cent) belonged to low level of adoption category followed by 34.17 per cent medium adoption level and only 30 per cent to high level of adoption. In nutshell, 70 per cent of farmers had low to medium level of adoption means i.e. farmers had not adopted the full package of practices recommended by the university. It may be due to poor knowledge of DSR coupled with long attachments with conventional method of cultivation. The study gets support from Kaur et al. (2011) who reported that considering the need of more technical knowledge for the adoption of DSR technology, the government should organize training programs for skill development.

Farmers' adoption level of DSR cultivation technology: It is evident from the results regarding farmer's adoption level of DSR cultivation technology presented in table 2 that 'method of sowing' and 'flat pan nozzle used for spray' were ranked $1^{\text {st }}$ with weighted mean score (3.00), 'depth of sowing' and 'seed treatment' were ranked $2^{\text {nd }}$ with weighted mean score (2.93), 'land preparation' ranked $3^{\text {rd }}$ with weighted mean score (2.88), 'recommended -weedicides-use' and 'interval schedule of irrigation followed' ranked $4^{\text {th }}$ and $5^{\text {th }}$ with weighted mean score (2.85) and (2.81), 'insect-pest control' ranked $6^{\text {th }}$ with weighted mean score (2.61), 'diseases control', 'sowing time' and sowing of 'recommended variety' ranked $7^{\text {th }}, 8^{\text {th }}$ and $9^{\text {th }}$ with weighted mean score (2.59), (2.52) and (2.43), 'harvesting at proper time' and 'time of irrigation' ranked $10^{\text {th }}$ and $11^{\text {th }}$ with weighted mean score (2.38) and (2.37), 'preparation and sowing' ranked $12^{\text {th }}$ with weighted mean score (2.28), 'recommended seed rate used' and 'timely application of fertilizers' ranked $13^{\text {th }}$ and $14^{\text {th }}$ with weighted mean score (1.94) and (1.87), 'recommended dose of fertilizers used' ranked $15^{\text {th }}$ with weighted mean score (1.73), 'ferrous sulphate use at iron deficiency syndrome' ranked $16^{\text {th }}$ with weighted mean score (1.35), and 'ferrous sulphate used as per recommendation' ranked $17^{\text {th }}$ with weighted mean score (1.19).

Recommended depth of sowing and seed treatment both were fully adopted by farmers because seed drill machine was operated at the time of sowing by expert. Weed infestation was the major problem of DSR farmers so recommended weedicides were also used by farmers. Majority of the farmers adopted insecticides and pesticides as per recommendation of the CCSHAU, Hisar. Sowing time was not adopted due to non - availability of seed drill machine, well in time to every farmer. More than 50 per cent farmers used recommended variety for sowing as per recommendation, while others did not use due to non-availability of seed or high cost of the seed. Chauhan (2013) found that in many Asian countries farmers are shifting from transplanting to direct seeding.

While harvesting at proper time was partially adopted by the farmers depending upon the availability of manual labour at the time of maturity or their schedule. About 50 per cent farmers partially adopted time of irrigation because they irrigated their crop according to their long mental process of conventional method regarding time. Farmers were not aware about timely application and recommended dose of fertilizers so they did not fully adopt. Ferrous sulphate was used at iron deficiency syndrome only and not as per recommendation due to lack of awareness and knowledge. The study gets support from findings of Min et al. (2011) who reported that direct seeding was an effective crop production method for reducing crop production costs and also water and soil conservation.

Constraints related to inputs perceived by farmers: The findings of the study (Table 3) revealed that among input constraints viz., 'non-availability of quality seeds, fertilizers, pesticides in required quantity and at proper time' ranked first with highest weighted mean score (1.64) followed by 'high cost of seed' ranked second with the weighted mean score (1.60), 'non-availability of inputs at village level' ranked third with the weighted mean score (1.57). 'Inadequate credit facilities for purchase of inputs' ranked as fourth and 'high prices of weedicides, chemical fertilizers, pesticides and fungicides' ranked fifth with weighted mean score of 1.43 and 1.41 , respectively. The findings, therefore, concluded that timely availability of quality inputs in required quantity and at proper time was not assured which was very much essential for sustainability of agriculture particularly food crops to ensure health and nutritional security of human beings. Findings are in consonance with past study of Oudhia 
(1999) who reported that 30 per cent farmers faced problems due to high cost of input like weedicides etc. Constraints related to production perceived by farmers: From results presented in Table 4 it is clear that among production constraints viz., 'high weed infestation in DSR in comparison to transplanting' ranked first constraint with highest weighted mean score (2.88), 'poor drainage facility' ranked second major constraint with the weighted mean score (2.39) and 'attack of insects pests' ranked third constraint with the weighted mean score (1.39) followed by 'low production due to unfavourable weather conditions' and 'attack of drought prone plant diseases' were ranked as fourth and fifth constraints with weighted mean (1.29) and (1.08), respectively.

The study revealed that weed infestation was the major problem and responsible to increase input cost and weeds competed with main crop plants for uptake of water, nutrients, etc. in decreasing the yield. The findings are in agreement with the findings of Muhammad et al. (2006) concluded that higher water requirements and increasing labour costs were the major problems of the traditional rice production system while Pathak et al. (2011) reported that direct-seeded rice (DSR) was a feasible alternative to conventional puddled transplanted rice with good potential to save water, reduce labour requirement, mitigate green-house gas (GHG) emission and adapt to climatic risks, Rehman et al. (2011) stated that poor and erratic crop stand was one of the major constraints to the wider adoption of direct-seeded rice at farmer's field and Weerakoon et al. (2011) found that most important production constraint for direct-seeded rice was in the dry zone (DZ) and intermediate zone (IZ).

Constraints related to marketing perceived by farmers: The results presented in Table 5 regarding constraints related to marketing show that 'wide fluctuation in prices' ranked first constraint with highest weighted mean score (2.83) and 'lack of storage facilities in village' ranked second major constraint with the weighted mean score (2.78), whereas 'lack of minimum support price' ranked third constraint with the weighted mean score (2.60). While 'low price of produce in spite of export-oriented food grain' was ranked as fourth constraint with the weighted mean score (2.83) followed by 'lack of cooperative organization for marketing of produce' ranked fifth constraint with the weighted mean score (2.08), 'lack of marketing facilities in village' ranked sixth constraint with the weighted mean score (1.97). 'High market charges for sieving, cleaning, loading and unloading of produce', 'lack of marketing knowledge \& intelligence' and 'lack of grading system' ranked seventh, eighth and ninth with weighted mean score of $1.71,1.33$ and 1.21, respectively.

The findings seem to be logical since farmers are forced to distress sale of produce ultimately hampering adoption of new technology oriented to export quality food grain production in view of wide fluctuation in prices even the minimum support price for which is not fixed by the government.

Constraints related to technical guidance perceived by farmers: Results presented in the table 6 revealed that among constraints related to technical guidance 'lack of proper knowledge about irrigation schedule' ranked first with highest weighted mean score (1.73), followed by 'non-availability of extension workers for technical guidance' which ranked second with weighted mean score (1.64), 'lack of knowledge of current advances in direct-seeded rice cultivation technology' as third major constraint with weighted mean score (1.40), whereas 'lack of guidance for proper sowing time' ranked fourth with weighted mean score (1.28), 'lack of guidance about recommended doses of new weedicides and their application techniques' ranked fifth with weighted mean score (1.25) and 'lack of guidance for controlling insect-pests \& diseases and application of pesticides and fungicides' ranked sixth constraint with weighted mean score (1.23).

Lack of proper knowledge about irrigation schedule' as the major constraint faced by the farmers related to technical guidance. Although the farmers had high adoption in case of irrigation schedule may be due to assured irrigation facilities but they have expressed as most serious constraint for technical guidance. Perusal of the data indicates that most crucial aspect like irrigation schedule which is core activity for success of DSR technology needs more result demonstration and further dissemination by the extension agencies for increasing the benefits of this resource conserving and eco-friendly rice production technology and concern of farmers regarding lack of knowledge of DSR technology along with lack of guidance related to weed control and insect-pest control seems to be logical that field functionaries are concerned only to supply inputs rather than technical advancement. The study got strength from Oudhia (1999) who reported that only 12.5 per cent farmers were aware about technical guidance.

Financial constraints perceived by farmers: The findings contained in Table 7 regarding perception about financial constraints reveal that 'lack of low interest-credit facility' ranked first with highest weighted mean score (1.62) followed by 'higher cost of farm machinery' and 'inadequate funds to buy seed drill, power sprayers, harvester and other farm implements' and 'no subsidy on seed drill machine' were ranked second, third and fourth constraints with weighted mean score (1.59), (1.36) and (1.21), respectively.

It can be concluded that 'lack of low interest-credit facility' is a major constraint faced by the farmers related to financial matters. Findings of the study seem to be logical since financial situation of the farmers plays a vital role in adoption of mechanization oriented technology like DSR for which a specially designed seed drill is required. 
Constraints related to information as perceived by farmers: An examination of the results presented in Table 8 indicates that among constraints related to information, viz., 'agricultural magazines and literature are not timely available in village' was ranked first with highest weighted mean score (2.78), 'no knowledge about Radio/T.V. programs related to DSR cultivation technology' was ranked second with weighted mean score (2.76) and 'poor knowledge about using cyber communication source' was ranked third with weighted mean score (2.72). While 'inadequate and incomplete information is given by input dealers' was ranked fourth constraint with weighted mean score (1.83), 'ADOs have poor knowledge about DSR cultivation technology' was ranked fifth with weighted mean score (1.32) and 'experts language is more scientific than local language' was ranked sixth constraint with lowest weighted mean score (1.15). 'Experts' language is more scientific than local language' was ranked sixth.

It is surprising to note that most reliable mass media like agricultural magazines and literature is not made timely available to farmers along with poor knowledge of radio \& TV programs pertaining to DSR technology which are essential for supplementing and complementing their knowledge of DSR as well as to reach largest number of farmers for its quickest acceptance by the farming community for sustainable food production. Similar findings have been reported by Oudhia (1999) that information was a major constraint and 42.5 per cent farmer faced that problem. Miscellaneous constraints perceived by the farmers: An examination of the findings presented in Table 9 indicates that miscellaneous constraints perceived by the farmers viz., 'lack of proper procurement policy of Govt.' ranked first constraint with highest weighted mean score (2.46), followed by 'lack of trained field extension staff to provide technical support throughout cultivation process' which ranked second constraint with weighted mean (2.02), 'non-availability of quality seed from Govt. agencies' ranked third constraint with weighted mean score (1.96) and 'high cost of seeds, chemical fertilizers, weedicides and pesticides, etc. was ranked fourth with lowest weighted mean score (1.48).

The findings pertaining to miscellaneous constraints perceived by the farmer show that 'lack of proper procurement policy of Govt.' was ranked first followed by 'lack of trained field extension staff to provide technical support throughout cultivation process' was ranked second. Findings of the study seem to be logical since remunerative price of produce and its demand along with higher technical skills of production are key components of adoption of new technology by farmers so government should take necessary steps like stable procurement policy for basmati rice and maximum number of trainings for updating technical knowledge and skill of field functionaries and farmers both for harnessing greater benefits of such eco-friendly and resource conservation technology in food production system.

Production related prospects of DSR cultivation technology: Table 10 elaborates the results pertaining to production related prospects of DSR cultivation technology in which majority of the farmers agreed on 'better economic returns in comparison to transplanting' with weighted mean score 2.95 occupied 1st rank, 'direct-seeded rice (DSR) cultivation require less water than transplanting' with weighted mean score 2.93 occupied 2 nd rank, followed by 'low production cost due to fully crop mechanization' occupied 3rd rank, 'your past experience favours the direct-seeded rice (DSR) over transplanting' occupied 4th rank, 'farmer friendly being easy to produce' occupied 5th rank, 'better quality of crop produce' occupied 6th and 'early maturity (7-10 days) results in timely sowing of succeeding crops' occupied 7th rank with weighted mean scores of 2.82, 2.78, 2.72, 2.68 and 2.29, respectively. 'Better economic returns in comparison to transplanting' as major prospect followed by 'directseeded rice (DSR) cultivation requires less water than transplanting' and 'low production cost due to fully crop mechanization' were perceived highly prospective aspects of technology. Whereas farmers were either undecided or disagreed on the aspects such as 'farmer friendly being easy to produce', 'better quality of crop produce' and 'early maturity (7-10 days) results in timely sowing of succeeding crop' which may be due to their poor knowledge or ignorance of these aspect. Singh et. al. (2013) have reported that farmers don't have full knowledge of scientific cultivation practices. It can be concluded that farmers are ready to adopt this technology due to better economic returns, requiring less water than traditional method and low production cost due to mechanization. Findings are in agreement with those of Tripathi (2004) who reported higher net returns over conventional transplanting. The findings of the study are in consonance with the study of Gill et al. (2006) who reported increased water productivity in case of DSR over transplanting. The findings of the study are also in consonance with the study of Gill et al. (2006) who reported short duration, early maturity excelled in productivity over medium and long duration varieties which means suitable for basmati group of rice.

General prospects of DSR cultivation technology: Results pertaining to general prospects of DSR cultivation technology presented in table 11 indicate that 'it is better being less labour requiring technology' with weighted mean score (2.92) occupied 1st rank, 'in case Govt. provides facility would you take up this technology as replacement of the transplanting' with weighted mean score (2.89) occupied 2nd rank, 'demand is increasing day by day in view of depleting water resources' with weighted mean score (2.85) occupied 3rd rank and 4th rank was given to 'best rice production technology in water crisis situation' with weighted mean score (2.83), while 'best resource conservation 
Table 1. Overall adoption level of DSR cultivation technology $(n=120)$.

\begin{tabular}{cccc}
\hline S. N. & Adoption level & Frequency & Percentage \\
\hline 1. & Low (38-43) & 43 & 35.83 \\
2. & Medium (44-47) & 41 & 34.17 \\
3. & High (47-51) & 36 & 30 \\
\hline
\end{tabular}

Table 2. Farmers' adoption level of DSR cultivation technology $(n=120)$.

\begin{tabular}{|c|c|c|c|c|c|c|c|}
\hline \multirow{2}{*}{$\begin{array}{l}\text { S. } \\
\text { N. }\end{array}$} & \multirow[t]{2}{*}{ Practice } & \multicolumn{3}{|c|}{ Adoption level } & \multirow{2}{*}{$\begin{array}{c}\text { Total } \\
\text { weighted } \\
\text { score }\end{array}$} & \multirow{2}{*}{$\begin{array}{l}\text { Weighted } \\
\text { mean score }\end{array}$} & \multirow{2}{*}{$\begin{array}{l}\text { Rank } \\
\text { order }\end{array}$} \\
\hline & & $\begin{array}{c}\text { Fully } \\
\text { adopted } \\
(\%)\end{array}$ & $\begin{array}{l}\text { Partially } \\
\text { adopted } \\
(\%)\end{array}$ & $\begin{array}{c}\text { Not } \\
\text { adopted } \\
(\%)\end{array}$ & & & \\
\hline 1. & Land preparation & $\begin{array}{l}108 \\
(90)\end{array}$ & $\begin{array}{c}9 \\
(7.50)\end{array}$ & $\begin{array}{c}3 \\
(2.50)\end{array}$ & 345 & 2.88 & III \\
\hline 2. & Method of sowing & $\begin{array}{c}120 \\
(100)\end{array}$ & 0 & 0 & 360 & 3.00 & I \\
\hline 3. & Preparation and sowing & $\begin{array}{c}48 \\
(40)\end{array}$ & $\begin{array}{c}57 \\
(47.5)\end{array}$ & $\begin{array}{c}15 \\
(12.5)\end{array}$ & 273 & 2.28 & XII \\
\hline 4. & Depth of sowing & $\begin{array}{c}112 \\
(93.33)\end{array}$ & $\begin{array}{c}8 \\
(6.67)\end{array}$ & 0 & 352 & 2.93 & II \\
\hline 5. & $\begin{array}{l}\text { Recommended variety } \\
\text { sown }\end{array}$ & $\begin{array}{c}82 \\
(68.33)\end{array}$ & $\begin{array}{c}8 \\
(6.67)\end{array}$ & $\begin{array}{l}30 \\
(25)\end{array}$ & 292 & 2.43 & IX \\
\hline 6. & Sowing time & $\begin{array}{c}67 \\
(58.83)\end{array}$ & $\begin{array}{c}48 \\
(40)\end{array}$ & $\begin{array}{c}5 \\
(4.16)\end{array}$ & 302 & 2.52 & VIII \\
\hline 7. & $\begin{array}{l}\text { Recommended seed } \\
\text { rate used }\end{array}$ & $\begin{array}{c}31 \\
(25.83)\end{array}$ & $\begin{array}{c}51 \\
(42.5)\end{array}$ & $\begin{array}{c}38 \\
(31.67)\end{array}$ & 233 & 1.94 & XIII \\
\hline 8. & Seed treatment & $\begin{array}{l}114 \\
(95)\end{array}$ & $\begin{array}{c}4 \\
(3.33)\end{array}$ & $\begin{array}{c}2 \\
(1.67)\end{array}$ & 352 & 2.93 & II \\
\hline 9. & $\begin{array}{l}\text { Recommended } \\
\text { weedicides use }\end{array}$ & $\begin{array}{c}103 \\
(85.83)\end{array}$ & $\begin{array}{c}16 \\
(13.33)\end{array}$ & $\begin{array}{c}1 \\
(0.83)\end{array}$ & 342 & 2.85 & IV \\
\hline 10. & $\begin{array}{l}\text { Flat pan nozzle used } \\
\text { for spray }\end{array}$ & $\begin{array}{c}120 \\
(100)\end{array}$ & 0 & 0 & 360 & 3.00 & I \\
\hline 11. & Time of irrigation & $\begin{array}{c}50 \\
(41.67)\end{array}$ & $\begin{array}{c}64 \\
(53.33)\end{array}$ & $\begin{array}{c}6 \\
(5)\end{array}$ & 284 & 2.37 & XI \\
\hline 12. & $\begin{array}{l}\text { Interval schedule of } \\
\text { irrigations followed }\end{array}$ & $\begin{array}{c}99 \\
(82.5)\end{array}$ & $\begin{array}{c}19 \\
(15.83)\end{array}$ & $\begin{array}{c}2 \\
(1.66)\end{array}$ & 337 & 2.81 & V \\
\hline 13. & $\begin{array}{l}\text { Recommended dose of } \\
\text { fertilizers used }\end{array}$ & $\begin{array}{c}9 \\
(7.5)\end{array}$ & $\begin{array}{c}70 \\
(58.33)\end{array}$ & $\begin{array}{c}41 \\
(34.17)\end{array}$ & 208 & 1.73 & XV \\
\hline 14. & $\begin{array}{l}\text { Ferrous sulphate use at } \\
\text { iron deficiency syn- } \\
\text { drome }\end{array}$ & $\begin{array}{c}2 \\
(1.67)\end{array}$ & $\begin{array}{c}38 \\
(31.67)\end{array}$ & $\begin{array}{c}80 \\
(66.66)\end{array}$ & 162 & 1.35 & XVI \\
\hline 15. & $\begin{array}{l}\text { Ferrous sulphate used } \\
\text { as per recommenda- } \\
\text { tion }\end{array}$ & $\begin{array}{c}3 \\
(2.5)\end{array}$ & $\begin{array}{c}17 \\
(14.17)\end{array}$ & $\begin{array}{c}100 \\
(83.33)\end{array}$ & 143 & 1.19 & XVII \\
\hline 16. & $\begin{array}{l}\text { Timely application of } \\
\text { fertilizers }\end{array}$ & $\begin{array}{c}9 \\
(7.5)\end{array}$ & $\begin{array}{c}86 \\
(71.67)\end{array}$ & $\begin{array}{c}25 \\
(20.83)\end{array}$ & 224 & 1.87 & XIV \\
\hline 17. & Disease control & $\begin{array}{c}79 \\
(65.83)\end{array}$ & $\begin{array}{c}33 \\
(27.5)\end{array}$ & $\begin{array}{c}8 \\
(6.67)\end{array}$ & 311 & 2.59 & VII \\
\hline 18. & Insect-pest control & $\begin{array}{c}78 \\
(65)\end{array}$ & $\begin{array}{c}37 \\
(30.83)\end{array}$ & $\begin{array}{c}5 \\
(4.17)\end{array}$ & 313 & 2.61 & VI \\
\hline 19. & $\begin{array}{l}\text { Harvesting at proper } \\
\text { time }\end{array}$ & $\begin{array}{c}54 \\
(45)\end{array}$ & $\begin{array}{c}58 \\
(48.33)\end{array}$ & $\begin{array}{c}8 \\
(6.67)\end{array}$ & 286 & 2.38 & $X$ \\
\hline
\end{tabular}

technology in food crops production system' with weighted mean score (2.58) occupied 5th rank, 'easy availability of power machinery like seed drill, sprayer and harvesters, etc.' with weighted mean score (2.55) occupied 6th rank, 'better input facilities are available' and 'better credit facilities are available at present' with weighted mean score (2.33) and (2.27) occupied 7th and 8th rank, respectively, whereas 'better technical support is available' occupied 9th rank, 'higher fertilizer use efficiency due to its placement in the root 
Table 3. Constraints related to inputs perceived by farmers $(n=120)$.

\begin{tabular}{|c|c|c|c|c|c|c|c|}
\hline \multirow{2}{*}{$\begin{array}{l}\text { S. } \\
\text { N. }\end{array}$} & \multirow[t]{2}{*}{ Input constraints } & \multicolumn{3}{|c|}{ Constraints } & \multirow{2}{*}{$\begin{array}{c}\text { Total } \\
\text { weighted } \\
\text { score }\end{array}$} & \multirow{2}{*}{$\begin{array}{l}\text { Weighted } \\
\text { mean } \\
\text { score }\end{array}$} & \multirow{2}{*}{$\begin{array}{l}\text { Rank } \\
\text { order }\end{array}$} \\
\hline & & $\begin{array}{c}\text { Very } \\
\text { serious } \\
(3)\end{array}$ & $\begin{array}{c}\text { Serious } \\
\text { (2) }\end{array}$ & $\begin{array}{l}\text { Not so } \\
\text { serious } \\
\text { (1) }\end{array}$ & & & \\
\hline 1. & $\begin{array}{l}\text { Non-availability of inputs at village } \\
\text { level }\end{array}$ & $\begin{array}{c}23 \\
(19.17)\end{array}$ & $\begin{array}{c}22 \\
(18.33)\end{array}$ & $\begin{array}{c}75 \\
(62.50)\end{array}$ & 188 & 1.57 & III \\
\hline 2. & High cost of seed & $\begin{array}{c}25 \\
(20.83)\end{array}$ & $\begin{array}{c}22 \\
(18.33)\end{array}$ & $\begin{array}{c}73 \\
(60.83)\end{array}$ & 192 & 1.60 & II \\
\hline 3. & $\begin{array}{l}\text { High prices of weedicides, chemi- } \\
\text { cal fertilizers, pesticides and fungi- } \\
\text { cides }\end{array}$ & $\begin{array}{c}20 \\
(16.67)\end{array}$ & $\begin{array}{c}9 \\
(7.50)\end{array}$ & $\begin{array}{c}91 \\
(76.83)\end{array}$ & 169 & 1.41 & $\mathrm{~V}$ \\
\hline 4. & $\begin{array}{l}\text { Non-availability of quality seeds, } \\
\text { fertilizers, weedicides and pesti- } \\
\text { cides in required quantity and at } \\
\text { proper time }\end{array}$ & $\begin{array}{c}18 \\
(15.00)\end{array}$ & $\begin{array}{c}41 \\
(34.17)\end{array}$ & $\begin{array}{c}61 \\
(50.83)\end{array}$ & 197 & 1.64 & I \\
\hline 5. & $\begin{array}{l}\text { Inadequate credit facilities for pur- } \\
\text { chase of inputs }\end{array}$ & $\begin{array}{c}18 \\
(15.00)\end{array}$ & $\begin{array}{c}16 \\
(13.33)\end{array}$ & $\begin{array}{c}86 \\
(71.67)\end{array}$ & 172 & 1.43 & V \\
\hline
\end{tabular}

Table 4. Constraints related to production perceived by farmers $(n=120)$.

\begin{tabular}{|c|c|c|c|c|c|c|c|}
\hline \multirow{2}{*}{$\begin{array}{l}\text { S. } \\
\text { N. }\end{array}$} & \multirow[t]{2}{*}{ Production constraints } & \multicolumn{3}{|c|}{ Constraints } & \multirow{2}{*}{$\begin{array}{c}\text { Total } \\
\text { weighted } \\
\text { score }\end{array}$} & \multirow{2}{*}{$\begin{array}{l}\text { Weighted } \\
\text { mean } \\
\text { score }\end{array}$} & \multirow{2}{*}{$\begin{array}{l}\text { Rank } \\
\text { order }\end{array}$} \\
\hline & & $\begin{array}{c}\text { Very } \\
\text { serious } \\
(3)\end{array}$ & $\begin{array}{l}\text { Serious } \\
\text { (2) }\end{array}$ & $\begin{array}{l}\text { Not so } \\
\text { serious } \\
\quad(1)\end{array}$ & & & \\
\hline 1. & $\begin{array}{l}\text { Low production due to unfavor- } \\
\text { able weather conditions }\end{array}$ & $\begin{array}{c}5 \\
(4.17)\end{array}$ & $\begin{array}{c}25 \\
(20.83)\end{array}$ & $\begin{array}{c}90 \\
(75.00)\end{array}$ & 155 & 1.29 & IV \\
\hline 2. & Poor drainage facility & $\begin{array}{c}58 \\
(48.33)\end{array}$ & $\begin{array}{c}51 \\
(42.50)\end{array}$ & $\begin{array}{c}11 \\
(9.17)\end{array}$ & 287 & 2.39 & II \\
\hline 3. & $\begin{array}{l}\text { High weed infestation in DSR in } \\
\text { comparison to transplanting }\end{array}$ & $\begin{array}{c}106 \\
(88.33)\end{array}$ & $\begin{array}{c}13 \\
(10.83)\end{array}$ & $\begin{array}{c}1 \\
(0.83)\end{array}$ & 345 & 2.88 & I \\
\hline 4. & $\begin{array}{l}\text { Attack of drought prone plant dis- } \\
\text { ease }\end{array}$ & $\begin{array}{c}2 \\
(1.67)\end{array}$ & $\begin{array}{c}6 \\
(5)\end{array}$ & $\begin{array}{c}112 \\
(93.33)\end{array}$ & 130 & 1.08 & $\mathrm{~V}$ \\
\hline 5. & Attack of insects-pests & $\begin{array}{c}5 \\
(4.17) \\
\end{array}$ & $\begin{array}{c}37 \\
(30.83) \\
\end{array}$ & $\begin{array}{c}78 \\
(65.00) \\
\end{array}$ & 167 & 1.39 & III \\
\hline \multirow{2}{*}{\multicolumn{2}{|c|}{$\begin{array}{l}\text { S. Marketing constraints } \\
\text { N. }\end{array}$}} & \multicolumn{3}{|c|}{ Constraints } & Total & Weighted & Rank \\
\hline & & $\begin{array}{c}\text { Very } \\
\text { serious } \\
(3) \\
\end{array}$ & $\begin{array}{l}\text { Serious } \\
\quad(2)\end{array}$ & $\begin{array}{l}\text { Not so } \\
\text { serious } \\
(1) \\
\end{array}$ & $\begin{array}{l}\text { weighted } \\
\text { score }\end{array}$ & $\begin{array}{l}\text { mean } \\
\text { score }\end{array}$ & order \\
\hline 1. & $\begin{array}{l}\text { Low price of produce in spite of } \\
\text { export oriented food grain }\end{array}$ & $\begin{array}{c}49 \\
(40.83)\end{array}$ & $\begin{array}{c}56 \\
(46.67)\end{array}$ & $\begin{array}{c}15 \\
(12.5)\end{array}$ & 274 & 2.83 & IV \\
\hline 2. & Lack of minimum support price & $\begin{array}{c}74 \\
(61.67)\end{array}$ & $\begin{array}{c}44 \\
(36.67)\end{array}$ & $\begin{array}{c}2 \\
(1.66)\end{array}$ & 312 & 2.60 & III \\
\hline 3. & $\begin{array}{l}\text { Lack of cooperative organization } \\
\text { for marketing of produce }\end{array}$ & $\begin{array}{c}30 \\
(25.00)\end{array}$ & $\begin{array}{c}69 \\
(57.5)\end{array}$ & $\begin{array}{c}21 \\
(17.5)\end{array}$ & 249 & 2.08 & $\mathrm{~V}$ \\
\hline 4. & Wide fluctuation in prices & $\begin{array}{c}107 \\
(89.17)\end{array}$ & $\begin{array}{c}12 \\
(10.00)\end{array}$ & $\begin{array}{c}1 \\
(0.83)\end{array}$ & 346 & 2.83 & I \\
\hline 5. & $\begin{array}{l}\text { Lack of marketing facilities in } \\
\text { village }\end{array}$ & $\begin{array}{c}16 \\
(13.33)\end{array}$ & $\begin{array}{c}84 \\
(70.00)\end{array}$ & $\begin{array}{c}20 \\
(16.67)\end{array}$ & 236 & 1.97 & VI \\
\hline 6. & $\begin{array}{l}\text { Lack of storage facilities in vil- } \\
\text { lage }\end{array}$ & $\begin{array}{c}100 \\
(83.33)\end{array}$ & $\begin{array}{c}14 \\
(11.67)\end{array}$ & $\begin{array}{c}6 \\
(5.00)\end{array}$ & 334 & 2.78 & II \\
\hline 7. & $\begin{array}{l}\text { Lack of marketing knowledge and } \\
\text { intelligence }\end{array}$ & $\begin{array}{c}1 \\
(0.83)\end{array}$ & $\begin{array}{c}38 \\
(31.67)\end{array}$ & $\begin{array}{c}81 \\
(67.50)\end{array}$ & 160 & 1.33 & VIII \\
\hline 8. & Lack of grading system & $\begin{array}{c}3 \\
(2.5)\end{array}$ & $\begin{array}{c}20 \\
(16.67)\end{array}$ & $\begin{array}{c}97 \\
(80.83)\end{array}$ & 146 & 1.21 & IX \\
\hline 9. & $\begin{array}{l}\text { High market charges for sieving, } \\
\text { cleaning, loading and unloading } \\
\text { of produce }\end{array}$ & $\begin{array}{c}18 \\
(15.00)\end{array}$ & $\begin{array}{c}49 \\
(40.83)\end{array}$ & $\begin{array}{c}53 \\
(44.17)\end{array}$ & 205 & 1.71 & VII \\
\hline
\end{tabular}


Table 6. Constraints related to technical guidance perceived by farmers $(\mathrm{N}=120)$.

\begin{tabular}{|c|c|c|c|c|c|c|c|}
\hline \multirow{2}{*}{$\begin{array}{l}\text { S. } \\
\text { N. }\end{array}$} & \multirow[t]{2}{*}{ Technical guidance constraints } & \multicolumn{3}{|c|}{ Constraints } & \multirow{2}{*}{$\begin{array}{c}\text { Total } \\
\text { weighted } \\
\text { score }\end{array}$} & \multirow{2}{*}{$\begin{array}{c}\text { Weighted } \\
\text { mean score }\end{array}$} & \multirow{2}{*}{$\begin{array}{l}\text { Rank } \\
\text { order }\end{array}$} \\
\hline & & $\begin{array}{l}\text { Very } \\
\text { serious } \\
\text { (3) }\end{array}$ & $\begin{array}{l}\text { Serious } \\
\text { (2) }\end{array}$ & $\begin{array}{l}\text { Not so } \\
\text { serious } \\
\text { (1) }\end{array}$ & & & \\
\hline 1. & $\begin{array}{l}\text { Lack of guidance for proper sowing } \\
\text { time }\end{array}$ & $\begin{array}{c}6 \\
(5.00)\end{array}$ & $\begin{array}{c}21 \\
(17.50)\end{array}$ & $\begin{array}{c}93 \\
(77.50)\end{array}$ & 153 & 1.28 & IV \\
\hline 2. & $\begin{array}{l}\text { Lack of guidance for controlling insect } \\
\text {-pests \& diseases and application of } \\
\text { pesticides and fungicides }\end{array}$ & $\begin{array}{c}2 \\
(1.66)\end{array}$ & $\begin{array}{c}23 \\
(19.17)\end{array}$ & $\begin{array}{c}95 \\
(79.17)\end{array}$ & 147 & 1.23 & VI \\
\hline 3. & $\begin{array}{l}\text { Lack of knowledge of current ad- } \\
\text { vances in direct-seeded rice cultivation } \\
\text { technology }\end{array}$ & $\begin{array}{c}5 \\
(4.16)\end{array}$ & $\begin{array}{c}38 \\
(31.67)\end{array}$ & $\begin{array}{c}77 \\
(64.17)\end{array}$ & 168 & 1.40 & III \\
\hline 4. & $\begin{array}{l}\text { Lack of guidance about recommended } \\
\text { doses of new weedicides and their } \\
\text { application techniques }\end{array}$ & $\begin{array}{c}2 \\
(1.66)\end{array}$ & $\begin{array}{c}26 \\
(21.67)\end{array}$ & $\begin{array}{c}92 \\
(76.67)\end{array}$ & 150 & 1.25 & V \\
\hline 5. & $\begin{array}{l}\text { Lack of proper knowledge about irri- } \\
\text { gation schedule }\end{array}$ & $\begin{array}{c}2 \\
(1.66)\end{array}$ & $\begin{array}{c}83 \\
(69.17)\end{array}$ & $\begin{array}{c}35 \\
(29.17)\end{array}$ & 207 & 1.73 & I \\
\hline 6. & $\begin{array}{l}\text { Non-availability of extension workers } \\
\text { for technical guidance }\end{array}$ & $\begin{array}{c}23 \\
(19.17)\end{array}$ & $\begin{array}{c}31 \\
(25.83)\end{array}$ & $\begin{array}{c}66 \\
(55.00)\end{array}$ & 197 & 1.64 & II \\
\hline
\end{tabular}

Table 7. Financial constraints perceived by farmers $(n=120)$.

\begin{tabular}{|c|c|c|c|c|c|c|c|}
\hline \multirow{2}{*}{$\begin{array}{l}\text { S. } \\
\text { N. }\end{array}$} & \multirow[t]{2}{*}{ Financial constraints } & \multicolumn{3}{|c|}{ Constraints } & \multirow{2}{*}{$\begin{array}{c}\text { Total } \\
\text { weighted } \\
\text { score }\end{array}$} & \multirow{2}{*}{$\begin{array}{c}\text { Weighted } \\
\text { mean score }\end{array}$} & \multirow{2}{*}{$\begin{array}{l}\text { Rank } \\
\text { order }\end{array}$} \\
\hline & & $\begin{array}{c}\text { Very } \\
\text { serious } \\
\quad(3)\end{array}$ & $\begin{array}{c}\text { Serious } \\
\text { (2) }\end{array}$ & $\begin{array}{l}\text { Not so } \\
\text { serious } \\
\quad(1)\end{array}$ & & & \\
\hline 1. & No subsidy on seed drill machine & $\begin{array}{c}2 \\
(1.67)\end{array}$ & $\begin{array}{c}21 \\
(17.50)\end{array}$ & $\begin{array}{c}97 \\
(80.83)\end{array}$ & 145 & 1.21 & IV \\
\hline 2. & Lack of low interest-credit facility & $\begin{array}{c}15 \\
(12.50)\end{array}$ & $\begin{array}{c}44 \\
(36.67)\end{array}$ & $\begin{array}{c}61 \\
(50.83)\end{array}$ & 194 & 1.62 & I \\
\hline 3. & $\begin{array}{l}\text { Inadequate funds to buy seed drill, } \\
\text { power sprayers, harvester and other } \\
\text { farm implements }\end{array}$ & $\begin{array}{c}10 \\
(8.33)\end{array}$ & $\begin{array}{c}23 \\
(19.17)\end{array}$ & $\begin{array}{c}87 \\
(72.50)\end{array}$ & 163 & 1.36 & III \\
\hline 4. & Higher cost of farm machinery & $\begin{array}{c}15 \\
(12.50)\end{array}$ & $\begin{array}{c}41 \\
(34.17)\end{array}$ & $\begin{array}{c}64 \\
(53.33)\end{array}$ & 191 & 1.59 & II \\
\hline
\end{tabular}

Table 8. Constraints related to information as perceived by farmers $(n=120)$.

\begin{tabular}{|c|c|c|c|c|c|c|c|}
\hline \multirow[t]{2}{*}{ S. N. } & \multirow[t]{2}{*}{ Information constraints } & \multicolumn{3}{|c|}{ Constraints } & \multirow{2}{*}{$\begin{array}{c}\text { Total } \\
\text { weighted } \\
\text { score }\end{array}$} & \multirow{2}{*}{$\begin{array}{l}\text { Weighted } \\
\text { mean score }\end{array}$} & \multirow{2}{*}{$\begin{array}{l}\text { Rank } \\
\text { order }\end{array}$} \\
\hline & & $\begin{array}{l}\text { Very } \\
\text { serious } \\
(3)\end{array}$ & $\begin{array}{l}\text { Serious } \\
\text { (2) }\end{array}$ & $\begin{array}{l}\text { Not so } \\
\text { serious } \\
\text { (1) }\end{array}$ & & & \\
\hline 1. & $\begin{array}{l}\text { ADOs have poor knowledge } \\
\text { about DSR cultivation } \\
\text { technology }\end{array}$ & $\begin{array}{c}11 \\
(9.17)\end{array}$ & $\begin{array}{c}16 \\
(13.33)\end{array}$ & $\begin{array}{c}93 \\
(77.50)\end{array}$ & 158 & 1.32 & $\mathrm{~V}$ \\
\hline 2. & $\begin{array}{l}\text { Experts language is more } \\
\text { scientific than local language }\end{array}$ & $\begin{array}{c}6 \\
(5.00)\end{array}$ & $\begin{array}{c}6 \\
(5.00)\end{array}$ & $\begin{array}{c}108 \\
(90.00)\end{array}$ & 138 & 1.15 & VI \\
\hline 3. & $\begin{array}{l}\text { No knowledge about Radio/ } \\
\text { T.V. programs related to } \\
\text { DSR cultivation technology }\end{array}$ & $\begin{array}{c}97 \\
(80.83)\end{array}$ & $\begin{array}{c}17 \\
(14.17)\end{array}$ & $\begin{array}{c}6 \\
(5.00)\end{array}$ & 331 & 2.76 & II \\
\hline 4. & $\begin{array}{l}\text { Agricultural magazines and } \\
\text { literature are not timely avail- } \\
\text { able in village }\end{array}$ & $\begin{array}{c}96 \\
(80.00)\end{array}$ & $\begin{array}{c}22 \\
(18.33)\end{array}$ & $\begin{array}{c}2 \\
(1.67)\end{array}$ & 334 & 2.78 & I \\
\hline 5. & $\begin{array}{l}\text { Poor knowledge about using } \\
\text { cyber communication source }\end{array}$ & $\begin{array}{c}92 \\
(76.67)\end{array}$ & $\begin{array}{c}22 \\
(18.33)\end{array}$ & $\begin{array}{c}6 \\
(5.00)\end{array}$ & 326 & 2.72 & III \\
\hline 6. & $\begin{array}{l}\text { Inadequate and incomplete } \\
\text { information is given by input } \\
\text { dealers }\end{array}$ & $\begin{array}{c}17 \\
(14.16)\end{array}$ & $\begin{array}{c}65 \\
(54.17)\end{array}$ & $\begin{array}{c}38 \\
(31.67)\end{array}$ & 219 & 1.83 & IV \\
\hline
\end{tabular}


Table 9. Miscellaneous constraints perceived by the farmers $(n=120)$.

\begin{tabular}{|c|c|c|c|c|c|c|c|}
\hline \multirow{2}{*}{$\begin{array}{l}\text { S. } \\
\text { N. }\end{array}$} & \multirow[t]{2}{*}{ Miscellaneous constraints } & \multicolumn{3}{|c|}{ Constraints } & \multirow{2}{*}{$\begin{array}{c}\text { Total } \\
\text { weighted } \\
\text { score }\end{array}$} & \multirow{2}{*}{$\begin{array}{l}\text { Weighted } \\
\text { mean } \\
\text { score }\end{array}$} & \multirow{2}{*}{$\begin{array}{l}\text { Rank } \\
\text { order }\end{array}$} \\
\hline & & $\begin{array}{l}\text { Very } \\
\text { serious } \\
\text { (3) }\end{array}$ & $\begin{array}{c}\text { Serious } \\
\text { (2) }\end{array}$ & $\begin{array}{c}\text { Not so } \\
\text { serious } \\
\text { (1) }\end{array}$ & & & \\
\hline 1. & $\begin{array}{l}\text { Non-availability of quality seed } \\
\text { from Govt. agencies }\end{array}$ & $\begin{array}{c}42 \\
(35.00)\end{array}$ & $\begin{array}{c}31 \\
(25.83)\end{array}$ & $\begin{array}{c}47 \\
(39.17)\end{array}$ & 235 & 1.96 & III \\
\hline 2. & $\begin{array}{l}\text { High cost of seeds, chemical fertil- } \\
\text { izers, weedicides and pesticides, } \\
\text { etc. }\end{array}$ & $\begin{array}{c}26 \\
(21.67)\end{array}$ & $\begin{array}{c}6 \\
(5.00)\end{array}$ & $\begin{array}{c}88 \\
(73.33)\end{array}$ & 178 & 1.48 & IV \\
\hline 3. & $\begin{array}{l}\text { Lack of proper procurement policy } \\
\text { of Govt. }\end{array}$ & $\begin{array}{c}62 \\
(51.67)\end{array}$ & $\begin{array}{c}51 \\
(42.50)\end{array}$ & $\begin{array}{c}7 \\
(5.83)\end{array}$ & 295 & 2.46 & I \\
\hline 4. & $\begin{array}{l}\text { Lack of trained field extension staff } \\
\text { to provide technical support } \\
\text { throughout cultivation process }\end{array}$ & $\begin{array}{c}43 \\
(35.83)\end{array}$ & $\begin{array}{c}36 \\
(30)\end{array}$ & $\begin{array}{c}41 \\
(34.17)\end{array}$ & 242 & 2.02 & II \\
\hline
\end{tabular}

Table 10. Production related prospects of DSR cultivation technology $(n=120)$.

\begin{tabular}{|c|c|c|c|c|c|c|c|}
\hline \multirow{2}{*}{$\begin{array}{l}\text { S. } \\
\text { N. }\end{array}$} & \multirow[t]{2}{*}{ Aspects } & \multicolumn{3}{|c|}{ Prospects level } & \multirow{2}{*}{$\begin{array}{c}\text { Total } \\
\text { weighted } \\
\text { score } \\
\end{array}$} & \multirow{2}{*}{$\begin{array}{l}\text { Weighted } \\
\text { mean } \\
\text { score }\end{array}$} & \multirow{2}{*}{$\begin{array}{l}\text { Rank } \\
\text { order }\end{array}$} \\
\hline & & Agree & Undecided & Disagree & & & \\
\hline 1. & Better quality of crop produce & $\begin{array}{c}92 \\
(76.67)\end{array}$ & $\begin{array}{c}17 \\
(14.17)\end{array}$ & $\begin{array}{c}11 \\
(9.16)\end{array}$ & 321 & 2.68 & VI \\
\hline 2. & $\begin{array}{l}\text { Better economic returns in } \\
\text { comparison to transplanting }\end{array}$ & $\begin{array}{c}116 \\
(96.66)\end{array}$ & $\begin{array}{c}2 \\
(1.67)\end{array}$ & $\begin{array}{c}2 \\
(1.67)\end{array}$ & 354 & 2.95 & I \\
\hline 3. & $\begin{array}{l}\text { Farmer friendly being easy to } \\
\text { produce }\end{array}$ & $\begin{array}{c}90 \\
(75)\end{array}$ & $\begin{array}{c}26 \\
(21.67)\end{array}$ & $\begin{array}{c}4 \\
(3.33)\end{array}$ & 326 & 2.72 & $\mathrm{~V}$ \\
\hline 4. & $\begin{array}{l}\text { Low production cost due to } \\
\text { fully crop mechanization }\end{array}$ & $\begin{array}{l}102 \\
(85)\end{array}$ & $\begin{array}{c}14 \\
(11.67)\end{array}$ & $\begin{array}{c}4 \\
(3.33)\end{array}$ & 338 & 2.82 & III \\
\hline 5. & $\begin{array}{l}\text { Early maturity ( } 7-10 \text { days) } \\
\text { results in timely sowing of } \\
\text { succeeding crop }\end{array}$ & $\begin{array}{c}39 \\
(32.5)\end{array}$ & $\begin{array}{c}77 \\
(64.17)\end{array}$ & $\begin{array}{c}4 \\
(3.33)\end{array}$ & 275 & 2.29 & VII \\
\hline 6. & $\begin{array}{l}\text { Direct-seeded rice (DSR) } \\
\text { cultivation require less water } \\
\text { than transplanting }\end{array}$ & $\begin{array}{c}113 \\
(94.17)\end{array}$ & $\begin{array}{c}5 \\
(4.16)\end{array}$ & $\begin{array}{c}2 \\
(1.67)\end{array}$ & 351 & 2.93 & II \\
\hline 7. & $\begin{array}{l}\text { Your past experience favours } \\
\text { the direct seeded rice (DSR) } \\
\text { over transplanting }\end{array}$ & $\begin{array}{l}102 \\
(84)\end{array}$ & $\begin{array}{c}9 \\
(7.5)\end{array}$ & $\begin{array}{c}9 \\
(7.5)\end{array}$ & 333 & 2.78 & IV \\
\hline
\end{tabular}

zone' occupied 10th rank and 'better export facilities are available' occupied 11th rank with weighted mean score $2.23,2.16$ and 2.05 , respectively.

The study reported that 'it is better being less labour requiring technology' as main prospect. The respondent farmers agreed that In case Govt. provides facilities they are ready to take up this technology as replacement of the transplanting' was second main general prospect of DSR cultivation technology followed by 'demand is increasing day by day in view of depleting water resources', prospective aspects agreed by farmers. Farmers of Punjab and Haryana are facing labour problem for transplanting due to shortage of migratory labour from Bihar and other states which have implemented MNREGA scheme. Similar findings were reported by Kaur et al. (2011). Use of submersible pump for irrigation is a clear indication of depletion of water sources and government has declared dark zones in these rice growing districts so DSR is the best alternative to save these dark zones to become darker.
Some times when farmers get higher prices in the market they even go for basmati rice cultivation in areas without assured irrigation or delayed onset of monsoon or early departure of it may create water crisis situation, in such situation the technology is most suitable. The finding of the study seems in agreement with scientifically proven facts like better water productivity and higher input use efficiency technology by past researches of Singh et al. (2005). Findings are also in agreement with the study of De (2010) who reported that adoption of hybrid can enhance the income of the farmers since this technology is multi advantageous and eco friendly as well. 'Better input facilities are available', 'better credit facilities are available at present' 'better technical support is available' and 'higher fertilizer use efficiency due to its placement in the root zone' and 'better export facilities are available' were ranked lower in agreement by farmers may be due to their ignorance or little concern about such aspects. 
Table 11. General prospects of DSR cultivation technology $(\mathrm{n}=120)$.

\begin{tabular}{|c|c|c|c|c|c|c|c|}
\hline \multirow{2}{*}{$\begin{array}{l}\text { S. } \\
\text { N. }\end{array}$} & \multirow[t]{2}{*}{ Aspects } & \multicolumn{3}{|c|}{ Prospects level } & \multirow{2}{*}{$\begin{array}{c}\text { Total } \\
\text { weighted } \\
\text { score }\end{array}$} & \multirow{2}{*}{$\begin{array}{l}\text { Weighted } \\
\text { mean } \\
\text { score } \\
\end{array}$} & \multirow{2}{*}{$\begin{array}{l}\text { Rank } \\
\text { order }\end{array}$} \\
\hline & & Agree & Undecided & Disagree & & & \\
\hline 1. & $\begin{array}{l}\text { Demand is increasing day by } \\
\text { day in view of depleting wa- } \\
\text { ter resources }\end{array}$ & $\begin{array}{c}109 \\
(89.17)\end{array}$ & $\begin{array}{c}9 \\
(7.5)\end{array}$ & $\begin{array}{c}4 \\
(3.33)\end{array}$ & 343 & 2.85 & III \\
\hline 2. & $\begin{array}{l}\text { Better technical support is } \\
\text { available }\end{array}$ & $\begin{array}{c}63 \\
(52.50)\end{array}$ & $\begin{array}{c}21 \\
(17.5)\end{array}$ & $\begin{array}{c}36 \\
(30)\end{array}$ & 267 & 2.23 & IX \\
\hline 3. & $\begin{array}{l}\text { Better credit facilities are } \\
\text { available at present }\end{array}$ & $\begin{array}{c}61 \\
(50.83)\end{array}$ & $\begin{array}{c}30 \\
(25)\end{array}$ & $\begin{array}{c}29 \\
(24.17)\end{array}$ & 272 & 2.27 & VIII \\
\hline 4. & $\begin{array}{l}\text { Easy availability of power } \\
\text { machinery }\end{array}$ & $\begin{array}{c}71 \\
(59.17)\end{array}$ & $\begin{array}{c}44 \\
(36.67)\end{array}$ & $\begin{array}{c}5 \\
(4.16)\end{array}$ & 306 & 2.55 & VI \\
\hline 5. & $\begin{array}{l}\text { Better input facilities are } \\
\text { available }\end{array}$ & $\begin{array}{c}65 \\
(54.17)\end{array}$ & $\begin{array}{c}30 \\
(25)\end{array}$ & $\begin{array}{c}25 \\
(20.83)\end{array}$ & 280 & 2.33 & VII \\
\hline 6. & $\begin{array}{l}\text { Higher fertilizer use effi- } \\
\text { ciency due to its placement in } \\
\text { the root zone }\end{array}$ & $\begin{array}{c}30 \\
(25)\end{array}$ & $\begin{array}{c}79 \\
(65.83)\end{array}$ & $\begin{array}{c}11 \\
(9.17)\end{array}$ & 259 & 2.16 & $X$ \\
\hline 7. & $\begin{array}{l}\text { Best resource conservation } \\
\text { technology in food crops pro- } \\
\text { duction system }\end{array}$ & $\begin{array}{c}76 \\
(63.33)\end{array}$ & $\begin{array}{c}38 \\
(31.67)\end{array}$ & $\begin{array}{c}6 \\
(5)\end{array}$ & 310 & 2.58 & $\mathrm{~V}$ \\
\hline 8. & $\begin{array}{l}\text { Best rice production technol- } \\
\text { ogy in water crisis situation }\end{array}$ & $\begin{array}{c}107 \\
(89.17)\end{array}$ & $\begin{array}{c}6 \\
(5)\end{array}$ & $\begin{array}{c}7 \\
(5.83)\end{array}$ & 340 & 2.83 & IV \\
\hline 9. & $\begin{array}{l}\text { Better export facilities are } \\
\text { available }\end{array}$ & $\begin{array}{c}30 \\
(25)\end{array}$ & $\begin{array}{c}67 \\
(55.83)\end{array}$ & $\begin{array}{c}23 \\
(19.17)\end{array}$ & 247 & 2.05 & XI \\
\hline 10. & $\begin{array}{l}\text { In case Govt. provides facility } \\
\text { would you take up this tech- } \\
\text { nology as replacement of the } \\
\text { transplanting? }\end{array}$ & $\begin{array}{c}109 \\
(90.83)\end{array}$ & $\begin{array}{c}9 \\
(7.5)\end{array}$ & $\begin{array}{c}2 \\
(1.67)\end{array}$ & 347 & 2.89 & II \\
\hline 11. & $\begin{array}{l}\text { It is better being less labour } \\
\text { requiring technology }\end{array}$ & $\begin{array}{c}113 \\
(94.17)\end{array}$ & $\begin{array}{c}4 \\
(3.33)\end{array}$ & $\begin{array}{c}3 \\
(2.5)\end{array}$ & 350 & 2.92 & I \\
\hline
\end{tabular}

Table 12. Prospects of DSR cultivation technology related to climate change $(n=120)$.

\begin{tabular}{|c|c|c|c|c|c|c|c|}
\hline \multirow{2}{*}{$\begin{array}{l}\text { S. } \\
\text { N. }\end{array}$} & \multirow[t]{2}{*}{ Aspects } & \multicolumn{3}{|c|}{ Prospects level } & \multirow{2}{*}{$\begin{array}{c}\text { Total } \\
\text { weighted } \\
\text { score }\end{array}$} & \multirow{2}{*}{$\begin{array}{c}\text { Weighted } \\
\text { mean score }\end{array}$} & \multirow{2}{*}{$\begin{array}{l}\text { Rank } \\
\text { order }\end{array}$} \\
\hline & & Agree & Undecided & Disagree & & & \\
\hline 1. & $\begin{array}{l}\text { Reduces the risk in } \\
\text { unfavourable weather } \\
\text { condition }\end{array}$ & $\begin{array}{c}35 \\
(29.17)\end{array}$ & $\begin{array}{c}66 \\
(55)\end{array}$ & $\begin{array}{c}19 \\
(15.83)\end{array}$ & 256 & 2.13 & III \\
\hline 2. & $\begin{array}{l}\text { Best suited to climate } \\
\text { change }\end{array}$ & $\begin{array}{c}84 \\
(70)\end{array}$ & $\begin{array}{c}31 \\
(25.83)\end{array}$ & $\begin{array}{c}5 \\
(4.17)\end{array}$ & 319 & 2.66 & I \\
\hline 3. & $\begin{array}{l}\text { Mitigation of the green } \\
\text { house gases emission }\end{array}$ & $\begin{array}{c}3 \\
(2.5)\end{array}$ & $\begin{array}{c}62 \\
(51.67)\end{array}$ & $\begin{array}{c}55 \\
(45.83)\end{array}$ & 188 & 1.57 & IV \\
\hline 4. & $\begin{array}{l}\text { An environment friendly } \\
\text { technology due to no } \\
\text { burning of rice residue }\end{array}$ & $\begin{array}{c}52 \\
(43.33)\end{array}$ & $\begin{array}{c}41 \\
(34.17)\end{array}$ & $\begin{array}{c}27 \\
(22.5)\end{array}$ & 265 & 2.21 & II \\
\hline
\end{tabular}

Prospects of DSR cultivation technology related to climate change: Results regarding prospects of DSR cultivation technology related to climate change. presented in Table 12 clearly indicate that it is 'best suited to climate change' with weighted mean score (2.66) occupied first rank, followed by 'an environment friendly technology due to no burning of rice residues' with weighted mean score (2.21) occupied second rank, 'reduces the risk in unfavourable weather condition' with weighted mean score (2.13) occupied third rank and 'mitigation of the green house gasses emission' with weighted mean score (1.57) occupied fourth rank.

Findings concluded that this technology is. 'best suited to climate change' followed by 'an environment friendly technology due to no burning of rice residue' and 'reduces the risk in unfavourable weather condition' were major prospective aspects agreed by farmers favouring adoption of technology while 'mitigation of the green house gases emission' ranked last may be due to their poor knowledge. It can be concluded that this is most feasible technology for ensuring food security in prevalent scenario of climate change every where and there. 
Suggested extension strategy for promoting the adoption of DSR cultivation: Overall adoption of DSR indicated that majority of the farmers belonged to low to moderate adoption categories. Farmers had expressed lack of proper knowledge of irrigation schedule and non-availability of extension workers for technical guidance as very serious constraints related to technical guidance of DSR technology. So, the reason for low adoption may be poor technical knowledge of both the farmers and field extension workers. So, more trainings and result demonstrations on farmers' fields with active participation of extension workers should be organized to update their knowledge as well as skills for establishment of this new technology on the farms. Moreover, the success stories of high adopters of this technology should be widely published through the mass media like radio, $\mathrm{TV}$, farm magazines and newspaper which should be also made timely available in villages.

1. Non-availability of quality seeds, fertilizers, weedicides and pesticides in required quantity and at proper time in village was very serious constraint perceived by farmers related to inputs of DSR cultivation. Problem of adulteration in seeds, fertilizers, weedicides and pesticides is very serious one. It is not only expressed by the farmers but also by other stake holders in agricultural development. The incidence of spurious inputs has been reported from time to time at different places. So, government should take stringent action against and defaulters' availability ensures the quality inputs for sustainability of farming.

2. Wide fluctuations of prices, lack of storage facilities and lack of minimum support price in case of basmati rice were perceived very serious constraints by the farmers which compelled them for distress sale of their produce. So, government should make stable policy regarding the procurement, fixing minimum support price and storage infrastructure at village level to ensure national food security as well sustainable and profitable farming of such export-oriented food grain.

3. The observations of farmers regarding lack of technical guidance related to irrigation schedule, advances of DSR technology and technical guidance related to weed control and insect- pest control seems to be logical that field functionaries are concerned with only supply of certain inputs and they either do not bother or update with the technical advances of DSR.

4. Farmers' observations related to financial matter seem to be logical in view of input intensive and mechanization of agriculture. So, Govt. should make provision of subsidy on seed drill or low interest rate credit to purchase inputs and machinery, etc. promote such type of resource conserving technology.

5. Although constraints such as inadequate and incomplete information by input dealers and poor knowledge of ADOs about DSR were perceived not so serious which seem to be illogical but probable reason may be their dependence on them for inputs like seeds, fertilizers and chemicals, etc. So, the technical knowledge of these functionaries should be updated for greatest success of DSR for sustainable food production.

6. Remunerative price of produce is very essential for making the agriculture enchanting profession which has been agreed by all sections of the society like farmers, scientists and even politicians who are demanding the fixation of minimum support price on the basis of Swami Nathan report.

7. Govt. or non-govt. organization should promote the establishment of producer companies in the area which will not only solve their problem of non-availability of quality seed but also help in getting higher returns by exporting their produce.

8. New molecules of herbicides efficient in controlling complex weed flora for solving the problem of weed infestation should be provided to the farmers.

9. Greater efforts are required for development of such hybrids which are vigorous in growth at early stages, drought tolerant and suppressing the weeds, etc.

\section{Conclusion}

The overall adoption of DSR cultivation technology was low to moderate The study also revealed that method of sowing, depth of sowing and seed treatment were highly adopted agronomic practices, whereas least adopted practices were recommended seed rate, timely application of fertilizers and their recommended doses, and ferrous sulphate use only at deficiency syndrome not as per schedule. It implies that more number of result demonstrations and skill development trainings of both farmers and field functionaries in participatory mode are required to be conducted at farmer field to establish this technology into the field. Among constraints non-availability of quality seeds, fertilizers, weedicides and pesticides in required quantity and at proper time, high weed infestation in DSR in comparison to transplanting, wide fluctuation in prices of basmati paddy due to lack of MSP, lack of storage facilities in villages, lack of proper knowledge of irrigation schedule, lack of low interest credit facility, non-availability of extension personnel, non-availability of agricultural magazines and literature in time in villages, lack of stable procurement policy for basmati rice and lack of trained field staff to provide technical guidance during cultivation process were serious constraints faced by farmers in adoption of DSR technology in Haryana. Concerted efforts should be made by government and non-government agencies to address the problems faced by farmers in adoption of DSR especially quality inputs and strengthening the capacity building of both field functionaries and farmers regarding DSR technology for its establishment in farmers' field. Since majority of respondent farmers agreed that DSR technology give better net returns in comparison to transplanting, 
less water requirement, less labour requirement and best suited to climate change risks. Promotion and establishment of such technology in the field is very essential for harnessing greater benefits of this eco-friendly and resource conservation technology to have a sustainable food production system ensuring food security and enhancement of farmers' income.

\section{REFERENCES}

Anonymous (2012). Deptt. of Economics and Statistics, Deptt. of Agriculture and Cooperation. Government of India.

Anonymous, (2013). Agricultural and Processed Food Products Expert Development Authority, Ministry of Commerce and Industry, Government of India.

Chauhan, B. S. (2013). Strategies to manage weedy rice in Asia. Crop Production, 48: 51-56.

De, Bibhas Kanti (2010). Employment and Income Generation in Paddy cultivation through Sri in Tripura. Journal of Community Mobilization and Sustainable Development, 5(2): 87-91.

Gill, M.S.,; Kumar, A. and Kumar, P. (2006). Growth and yield of rice (Oryza saliva) cultivars under various methods and times of sowing. Indian Journal of Agronomy, 51(2):123-127.

Kaur, Manjeet;, Mahal,A.K. and Sekhon, M.K. (2011). Adoption of Labour-saving Technology in Paddy Transplantation- Micro-Level Evidences from Punjab. Agricultural Economics Research Review, 24: 568.

Min, Haung;, Zou,-Yingbin,; Feng,-Yuehua;, Cheng, -Zhaowei;, Mo-Yali;, Lbrahim,-Md;, Xia,-Bing;, Jiang,Peng (2011). No-tillage and direct seeding for super hybrid rice production in rice-oilseeds rape cropping system. European Journal of Agronomy, 34(4): 278286.

Muhammad Farooq, S.M.A. Basra, R. Tabassum and I. Afzal. (2006). Enhancing the performance of direct seeded fine rice by seed priming. Plant Prod. Sci., 9(4): 446-456.

Mukteshawar, R. and Shehrawat, P.S. (2015). Farmers' awareness and perception towards greenhouse gases (GHG) emission. Annals of Biology, 31(1): 141-146.

Oudhia, O. (1999). Chhattishgarh Farmers response in control of weeds in Direct seeded rice. Agric. Sci. Digest, 19(4): 261-263.

Pathak, H;., Tewri, A.N;., Sankyan, S. Dubey, D.S., Mina, U;, Singh. U.K., Jain, N,; Bhatia (2011). A Directseeded rice: potential, performance and problems a review. Current advances in Agricultural Sciences, 3(2): $77-$ 78.

Rehman, H;., Shahzad Maqsood Ahmed Basra and Muhammad Farooq (2011). Field appraisal of seed priming to improve the growth, yield and quality of direct seeded rice. Turk Jou. Agric, 35: 357-365.

Singh, R; Hansra, B.S. and Chand, Ramesh (2013). Knowledge and Adoption Level of Farmers of Haryana about Scientific Rice Cultivation Practices. Journal of Community Mobilization and Sustainable Development, 8 (1): 24-28.

Singh, Y.,; Singh, G.,; Singh, V.P.,; Singh, Pratibha.,; Hardy, B. Johnson.,; D.E. and Mortimer, M. (2005). Direct seeding of rice and weed management in the irrigated rice wheat cropping system of the Indo Gangetic Plains. Directorate of Experiment Stations, G.B. Pant University of Agriculture and Technology, Pantnagar, India.

Tripathi, J.,; Bhatta, M.R.,; Justice, S. and Shakya, N.K. (2004). Direct seeding: An emerging resource conserving technology for rice cultivation in the rice-wheat system. In: Proc. $24^{\text {th }}$ national summer crops research workshop. July 8-10, 2004, Lalitput, Nepal. Pp. 273-281.

Weerakoon, W.M.B; M.M.P. Mutunayake; C. Bandara; A.N. Rao; D.C. Bhandari, J.K. Ladha (2011). Direct seeded rice culture in Sri Lanka: Lessons from farmers. Field Crops Research, 121: 53-63. 